\title{
Problem-Based Learning (PBL) in Industry 4.0: Improving Learning Quality through Character-Based Literacy Learning and Life Career Skill (LL-LCS)
}

\author{
Muhammad Nurtanto ${ }^{1,2, *}$, Herminarto Sofyan ${ }^{1}$, Moh Fawaid ${ }^{2}$, Rabiman Rabiman ${ }^{1,3}$ \\ ${ }^{1}$ Technical and Vocational Education, Yogyakarta State University, Indonesia \\ ${ }^{2}$ Department of Mechanical Engineering Education, Universitas Sultan Ageng Tirtayasa, Indonesia \\ ${ }^{3}$ Departement of Mechanical Engineering Education, Universitas Sarjanawiyata Tamansiswa, Indonesia
}

Received September 24, 2019; Revised October 23, 2019; Accepted October 26, 2019

Copyright $\mathrm{O} 2019$ by authors, all rights reserved. Authors agree that this article remains permanently open access under the terms of the Creative Commons Attribution License 4.0 International License

\begin{abstract}
The rapid flow of globalization should be absorbed and implemented in education, especially learning. The industry 4.0 era and millennial, $21^{\text {st }}$ Century Education, and Sustainable Development Goals are intended for the purpose of learning and innovation skills. The researchers' objective is to improve the quality of learning by applying the literacy movement, character values as a provision for life and career skills using the PBL method in the gasoline engine curriculum. The research method is classroom action research with the Elliot action model carried out in two cycles. A total of 34 students with ages $\pm 19-22$ were used as research samples. The results obtained during the study showed an increase, namely: (a) the literacy movement was observed as successfully implemented with an increase of $19.1 \%$; (b) inducing character values improves student behavior by $14.8 \%$, and (c) strengthening competency in the gasoline motorbike curriculum by $11.3 \%$. Problems in the engineering field that are packaged in PBL classes through student literacy and character movements are some forms of learning innovation that need to be applied to similar competencies.
\end{abstract}

Keywords PBL, Learning Quality, Literacy Learning, Life Career Skills, Improving Learning.

\section{Introduction}

Researchers have seen a shift in the quality of education in Indonesia and it requires serious attention. Competition in the globalization era is so fast, several issues like the industrial era 4.0, Sustainable Development Goals [1], and 21 st-century education must be applied in education, with the intention of being able to keep up with the competition [2]. Moreover, equal distribution in the education sector is still an obstacle to the implementation. Therefore, educators must be sensitive to the issues and change the climate by improving quality independently and sustainably.

The era of globalization in the education context is directed at learning and innovation skills and considering long-term environmental sustainability [3]. Learning skills and innovations in question are (a) the ability to think critically and solve problems, (b) the ability to communicate and collaborate, and (c) creativity and innovation. Whereas the concern for the environment is reflected in the application of $5 \mathrm{~S}$, reusing waste materials, the development of soft skills and characters. Both of these aspects need to be implemented by the role of educators in the learning and school atmosphere.

In the current conditions, the government hopes for improvement in human resources by developing vocational education. This is evidenced by a large number of vocational education, the establishment of leading-competency-based schools, and the promotion of cooperation with various industries. Thus the competencies of graduates are expected to be in the form of life and career skills [4].

The condition is not easy though, the problem of the absorption of graduates towards the workforce is low, high level of juvenile delinquency, weak moral and character of the students, the less dynamic interest for reading, writing and listening. The government and education activists are mediators in providing solutions. One of the initiatives is the curriculum revision, the 2013 revised curriculum, which emphasizes learning with the characteristics of $5 \mathrm{M}$ with a scientific approach. Also, the application of literacy in learning includes reading literacy, information, media, 
and ICT as information and technology media skills.

The approach using scientific methods is a learning process that is actively designed by shifting the conventional mindset that is centered on the teacher. The scientific method is inseparable from the activities of $5 \mathrm{M}$, namely observing, asking, trying, reasoning, and communicating. During the learning process, the educator innovates by applying literacy and caring about the environment attitude to students. The scientific learning model is project-based learning (PjBL), Discovery Learning and problem-based learning (PBL). The learning model needs to be implemented, researched and developed by educators to improve the quality of learning. Thus educators need to prepare learning tools with the chosen model approach. The teacher must be able to design and choose the right model.

Learning characteristics in vocational education are dominated by the formation of hard skills and soft skills. While the general characteristics of learning in the automotive field are repairing system failures. This characteristic is identical to problem-based learning (PBL). This means that students while repairing problems on various components are expected to be able to master critical thinking skills [5] and [6], collaboration in teams / social interactions, and soft skills.

PBL is a pedagogic focused on active students [7], and [8] in a learning environment in the form of problem-solving with analytical and data skills. However, the focus of PBL is not in resolving the problem, but the process of gaining experience, social interaction and communication, and group collaboration as professional competencies. With the problem's identification through analysis and data-based process, students are expected to be able to make and present reports and then innovations will emerge. PBL can also be integrated with character values to prepare life and career skills, for instance, religious, curious, communicative, creative, discipline, caring for the environment and being responsible (adaptation from the Ministry of National Education, 2011). Broadly speaking, it consists of personal and social skills [9]. Moreover, PBL can implement literacy, namely information, reading, media, and ICT [10].

The competency in this research using the PBL method is gasoline engines. The complexity of the gasoline engines competency increases the thinking ability and good group collaboration because the maintenance carried out includes two aspects, engine, and electricity. Through these competencies, students will have knowledge for certain professions [11]. The two disciplines [12] have different characteristics in their repairs and damages. Prior to the implementation of learning, in preparing PBL-based tools, educators observed and interviewed the automotive industry regarding common damages. From the damages obtained, they are analyzed for the learning stage. The learning stages are carried out in 2 cycles. Researchers, in the first cycle, gave problems that are in line with the objective that students should be adapting to PBL stages and the mindsets analysis should not be much different. In the second cycle, students are given unstructured problems. Learning gasoline engine is categorized to be successful there is an increase in the output with class completeness of $80 \%$ from the total number of students. In addition, evaluation is needed on the implementation of literacy and life skills and career skills that are integrated with character values.

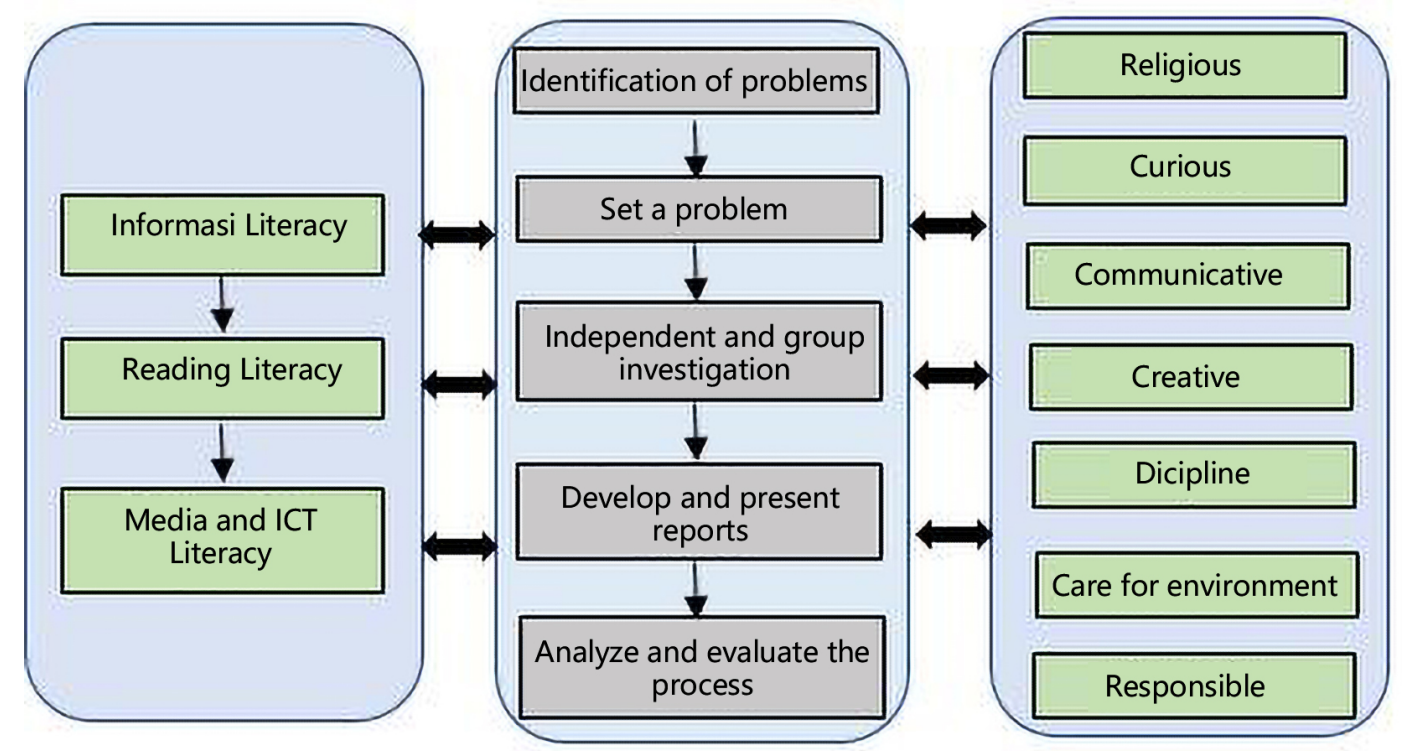

Figure 1. Learning and Innovation Skill in PBL 
Learning is done in three stages, introduction, main and closing. Introductory activities consist of opening, instilling and familiarizing spiritual attitudes through praying, giving apperception to the gasoline engine curriculum of the previous meeting, delivery of learning objectives for the gasoline engine (diagnosing damage, identifying damage and then repair the gasoline engine). The syntax of PBL stage 1 is stated in "weak spark plug flame" in hot conditions, the engine sound is unstable [13]. Let some students examine the condition and then explain it to other students. Educators develop critical thinking by testing the initial abilities through questions about the presumption of the cause.

The main learning stage, applying the PBL 2 syntax in the form of identifying the problem by finding and developing the cause. Students do literacy reading and collecting information through books, repairs and internet media. Educators train students to think critically about how to solve problems with several questions. Students should answer according to the understanding they gain from the literacy results. Next is the PBL 3 syntax: independent and group investigation in a diagnosis process. Students form groups of 5-6 people [14], [15] and [16]. At the engine stand, which has been set to the ignition problem, the team collaborates to find the cause. Information literacy takes place at this stage. The data obtained in group work is presented in the report. PBL stage 4 syntax: composing and presenting reports. Educators, assisted by ICT media and net modes, make reports in the form of comparative charts by comparing standard specifications and causal factors. PBL stage 5 syntax: analyzing and evaluating the process. In groups, students prepare the report with the help of laptop media and engine stand. The team leader opens the presentation and lets the members present the report results. All groups should make their presentations in front of the class. Educators ask them based on the reports to find solutions (develop creativity and innovation). Next, replace the problematic component.

The closing phase of learning: still a series of stages 5 , educators conclude the results of the problem and ask students to conclude the results of the learning cycle I. Cycle I learning activities have been completed and then instill care for the environment. The final stage applies religious culture with a closing prayer.

\section{Methods}

Researchers applied classroom action research (CAR) [17], developed from Eliott's model, 2001 ended in Cycle II. The reinforcement in this study lies in the reflection action that is used as an improvement step. The population is all students in semester VI who are aged $\pm 19-22$ and are grouped based on random group characteristics.

PBL implementation was carried out in a group of 6 people [9]. The division of groups is based on the willingness of students to become group leaders. Next is the random selection of group members. The intended purpose is to avoid coercion in learning and encourage collaboration and social interaction in the form of convenient communication.

In the first cycle of PBL learning, we have the same problem competencies with different component damage. The problem given is that the vehicle has a faltering or limping sound. This problem is set on the engine to stand with damage to the ignition system and fuel system, namely manifold solenoid.

During the learning process, the engine stand, hand tool, measurement tool, and assessment sheet were used. Assessment sheets consist of literacy activities (information media and technology skill), character content (life and career skills) using a Likert scale (1-5). Hard skill assessment sheet is used to assess performance [18] with the criteria of tools usage and work attitudes [19], ability to analyze a job, speed of doing assignments, ability to understand images and symbols, and harmony, with rating scales on a $0,1,2$, and 3 .

Literacy in PBL consists of 3 variables, namely information literacy, reading literacy, media, and ICT literacy. While the character content in PBL consists of 7 variables, namely religious, curious, communicative, creative, discipline, care about the environment, and to be responsible. On performance competencies (hard skills), we have 5 variables, namely preparation, process, results, attitude, and time during PBL.

The success of the action is determined by an increase in the action cycle with an average of $80 \%$ of students in the PBL class complete the lesson. The quantitative data are then analyzed. They were analyzed by presenting the percentage of and converted descriptively by which was calculated from the beginning to the end of data collection, [20].

\section{Result and Discussion}

\subsection{Result}

Table 1. Literacy Movement on PBL

\begin{tabular}{|c|c|c|c|}
\hline Literacy Variable & Cycle I & Cycle II & $\mathbf{P}_{\text {C1-C2 }}$ \\
\hline Information Literacy & 3,33 & 4,25 & 0,92 \\
\hline Reading Literacy & 3,50 & 4,56 & 1,06 \\
\hline Media and ICT Literacy & 3,22 & 4,11 & 0,89 \\
\hline Average & $\mathbf{3 , 3 5}$ & $\mathbf{4 , 3 1}$ & $\mathbf{0 , 9 5}$ \\
\hline
\end{tabular}

The literacy movement has increased by 0.95 (19.1\%). In the first cycle, the literacy movement of 3.50 showed the highest assessment of the information literacy movement and ICT media literacy variables. In the first cycle, all literacy obtained an average of 3.35. In cycle II all literacy $\geq 4.0$. The highest literacy movement was on reading 
literacy with 4.56 . The overall average literacy during the learning process using PBL is 4.31 .

Table 2. Character Score in PBL

\begin{tabular}{|c|c|c|c|}
\hline Character Variable & Cycle I & Cycle II & $\mathbf{P}_{\text {C1-C2 }}$ \\
\hline Religious & 4,25 & 5,00 & 0,75 \\
\hline Curious & 3,56 & 4,44 & 0,89 \\
\hline Communicative & 3,50 & 4,44 & 0,94 \\
\hline Creative & 3,78 & 4,61 & 0,83 \\
\hline Discipline & 4,08 & 4,67 & 0,58 \\
\hline Care for environment & 4,25 & 4,75 & 0,50 \\
\hline Responsible & 4,00 & 4,67 & 0,67 \\
\hline Average & $\mathbf{3 , 9 2}$ & $\mathbf{4 , 6 5}$ & $\mathbf{0 , 7 4}$ \\
\hline
\end{tabular}

Character values implemented have increased by 0.74 (14.1\%). In Cycle I with a score of $\geq 4.0$ in sequence, namely: religious and care for the environment at 4.25 ; discipline 4.08; and responsible 4.00. While in Cycle II all character variables are above the score of 4.0 with the highest is for religious 5.00. The average overall character values for Cycle I and Cycle II are 3.92 and 4.65. The highest improvement in character aspects is communicative.

Table 3. Hard skill score in PBL

\begin{tabular}{|c|c|c|c|}
\hline Hard Skill Variable & Cycle I & Cycle II & $\mathbf{P}_{\mathbf{C 1}-\mathbf{C 2}}$ \\
\hline Work preparation & 3,17 & 4,00 & 0,83 \\
\hline Work process & 3,33 & 4,17 & 0,83 \\
\hline Work result & 4,17 & 4,67 & 0,50 \\
\hline Work attitude & 4,50 & 4,67 & 0,17 \\
\hline Work duration & 4,00 & 4,50 & 0,50 \\
\hline Average & $\mathbf{3 , 8 3}$ & $\mathbf{4 , 4 0}$ & $\mathbf{0 , 5 7}$ \\
\hline
\end{tabular}

The increase from cycle I to cycle II is 0.57 (11.3\%) with the average of Cycle I is 3.83 and cycle II is 4.63 . For the score of $\geq 4.0$ in sequence as follows: work attitude, work duration, work result. The improvements made in the second cycle of all hard skill components are more than 4.00. The highest increase in hard skill aspects is work preparation.

\subsection{Discussion}

The results were obtained during the learning process of the gasoline engine curriculum with the PBL method. It is necessary to discuss the aspects of action and the success percentage based on assessment indicators. Each aspect as a whole was considered to be successful when it was at least in the "good enough" category.

The first cycle in figure 2 (a) indicates the bad category of $10 \%$, good enough $49 \%$, good at $38 \%$ and very good at $3 \%$. The results of reflection actions are able to improve Cycle II with each of the following categories as follows: good enough $10 \%$, good $50 \%$, and very good $40 \%$. The second cycle was declared successful, it can be seen that all aspects in the category were quite good. In this case, the literacy movement was declared successful.

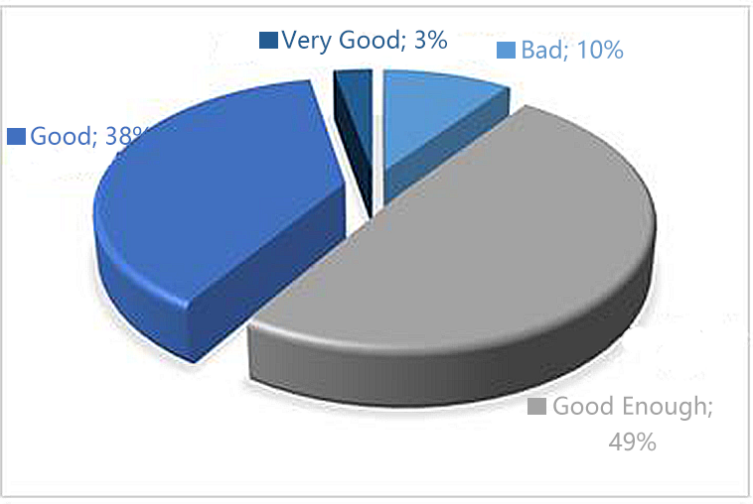

(a)

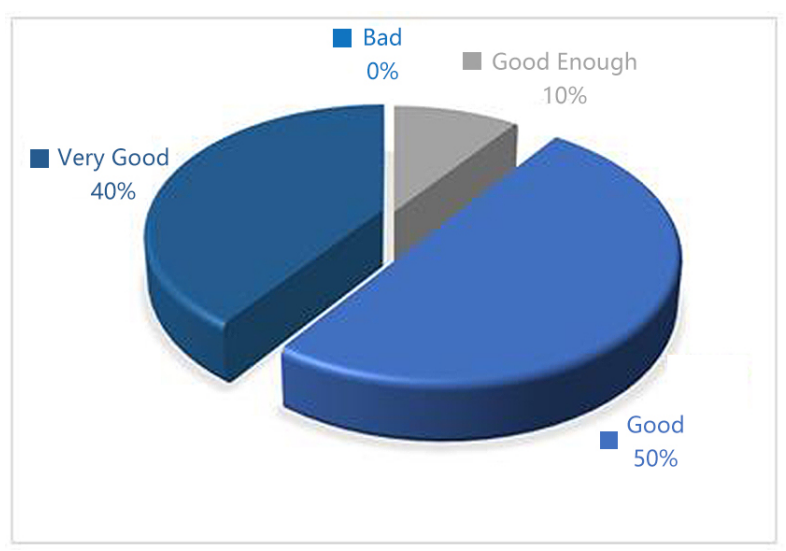

(b)

Figure 2. Literacy Movement Achievement Percentage in (a) Cycle I and (b) Cycle II

If we look at the indicators, $10 \%$ of the cycle I, there are 5 groups that get a score of 2 or "not good" and they are on: communicating tasks and using information sources on information literacy; suitability of sources on reading literacy; and computer and hardware usage in ICT and media literacy. From the analysis, during the action, we found that teamwork is not maximum. The task distribution that should have been carried out by the team leader has not run optimally. Furthermore, there are still groups that have difficulty using net modes during the learning process. As a result, sources obtained from the internet are less reliable. There are teams that were not yet proficient in operating computers and were not used to a projector. The results of the reflection were to maximize the role of the teacher as facilitator. By giving direction so that communicators in the team are more harmonious

In Cycle II, the planned action was able to increase 10\% in the "not good" category to be $10 \%$ "good enough" which was originally $49 \%$. In addition, the literacy in the "good" category initially $38 \%$ increased to $50 \%$, as well as "very good" literacy from $3 \%$ to $40 \%$. This happens because of several factors: (1) students understand the stages in implementing PBL and literacy movements are "habituation"; (2) the role of the teacher as a facilitator and director during PBL is getting better; and (3) reflection at 
the end of the action as a key evaluation to increase group potential.

Good learning includes applying character functions, one of which is to prepare life skills to find jobs. Character education must be done continuously as a "long-life education". All learning methods chosen by educators must at least apply character values. Because character values that are not included as learning objectives will make students unaware of them in their actions. But if it is controlled in a learning environment as one success indicator of learning, it will make students behave more carefully.

The results obtained in educating character values using the PBL method in the gasoline engine curriculum, are divided into 7 (seven) variables, namely: (1) religious; (2) curious; (3) communicative; (4) creative; (5) discipline; (6) care for the environment; and (7) sense of responsibility. Success based on the percentage obtained on the action cycle can be observed in figure 3 below:

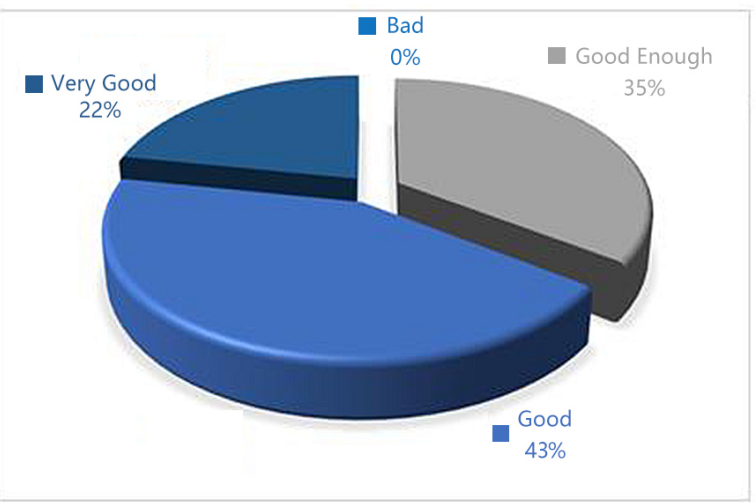

(a)

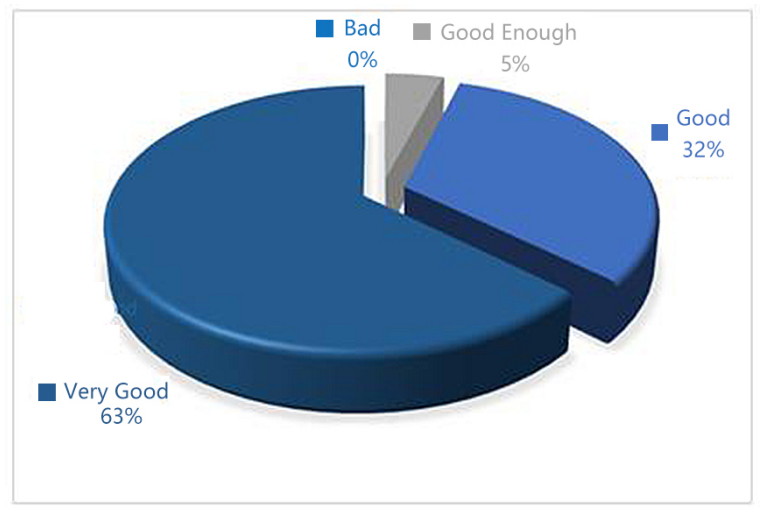

(b)

Figure 3. Movement Achievement Percentage in (a) Cycle I and (b) Cycle II
Overall, educating character values was declared successfully implemented. This is evidenced by the value of the indicator that is above a specified limit, which is "good enough". If we observe the increase in each cycle, the "good enough" indicator initially $35 \%$ decreases to $4 \%$. This is part of the success of the actions taken resulting from the reflection stage. Indicatively, the change that occurs lies in the habit of giving thanks; pay attention to the work of other team members; conclude the results correctly in the team; environmental care by cleaning the tools, and working in groups. All indicators that are "good enough" are reflected to improve the quality of learning.

The indicators above increased evenly on the other indicators, namely "good" category from $43 \%$ decreased to $29 \%$. This decrease is an improvement because it fills into the "very good" category. The "very good" category originally only $22 \%$ increased to $67 \%$. This means that the most increase happens in this category.

Three indicators are in the lower cluster, namely curious, communicative, and creative are in the category of "good enough". In analyzing the data, based on group performance in PBL [21], [22], the condition is caused by: (1) the new team requires adaptation, especially at the stages of finding the appropriate cause of damage, supporting information and paying attention to the performance of others as a provision of individual competence (2) two-way communication is needed in gathering assignments, information and final results in order to obtain definite answers; and (3) awareness in the examination trial, looking for a comparison from the uncommon answers The things above require habituation in planting character values. In the concept of character, learning must be able to link these values. In an implementation, PBLt is seen to provide a good increase in the character of students. This opinion is in line with [20] that PBL contributes to changes in student attitudes [23].

Hard skills, as well as psychomotor competencies, are the main competencies in practical work that can be measured easily [15]. Good practice assessment is carried out by observing the process and the final results. Preparation, attitude in work and time of completion are also indicators that need to be controlled. The goal is that basic abilities become more important in influencing the process and the final results.

This assessment is based on team performance during the learning process with the implementation of the PBL method. The percentage increase based on hard skill aspects is as follows 


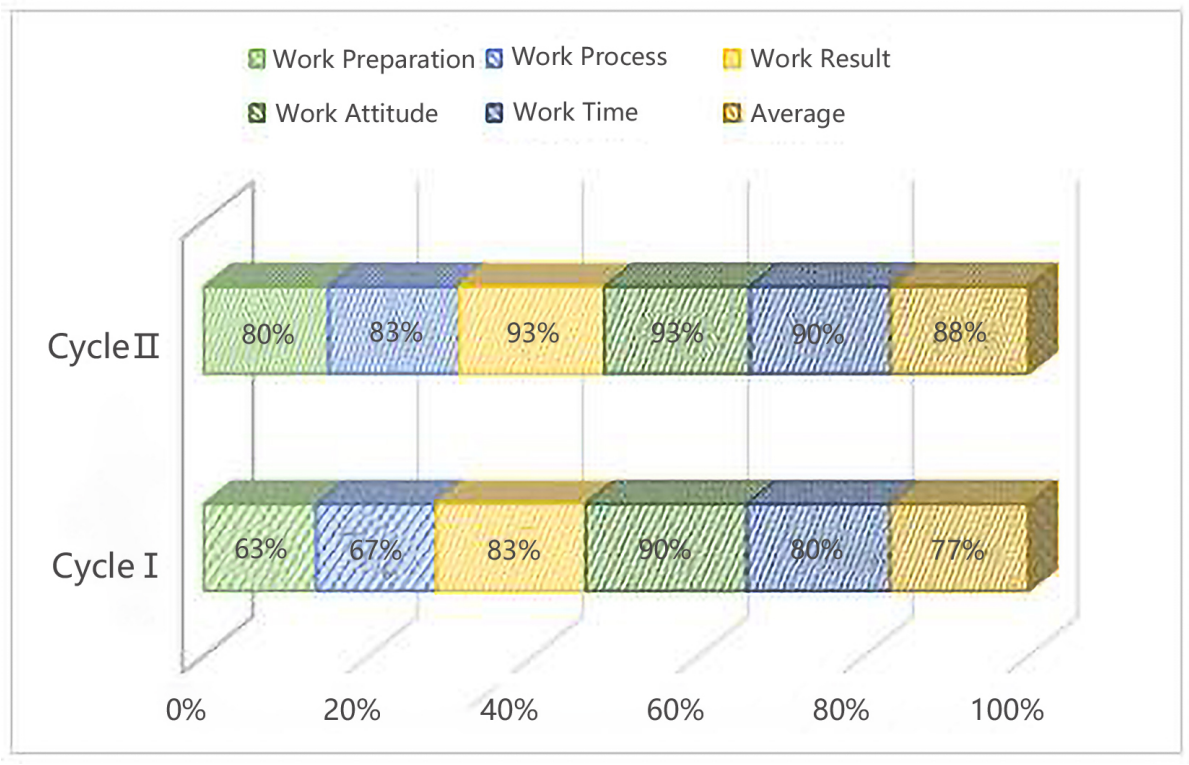

Figure 4. Hard Skill Percentage Outcome

Significant results are shown in work preparation, from $63 \%$ to $80 \%$. Similar aspects of the work process, from $67 \%$ to $83 \%$. This is an achievement in increasing the students' competence. In the team performance, there are 2 groups that are still in the unsuccessful category, and the action cycle provides significant changes. Other aspects have shown the same increase but the percentage in cycle I have had a positive impact.

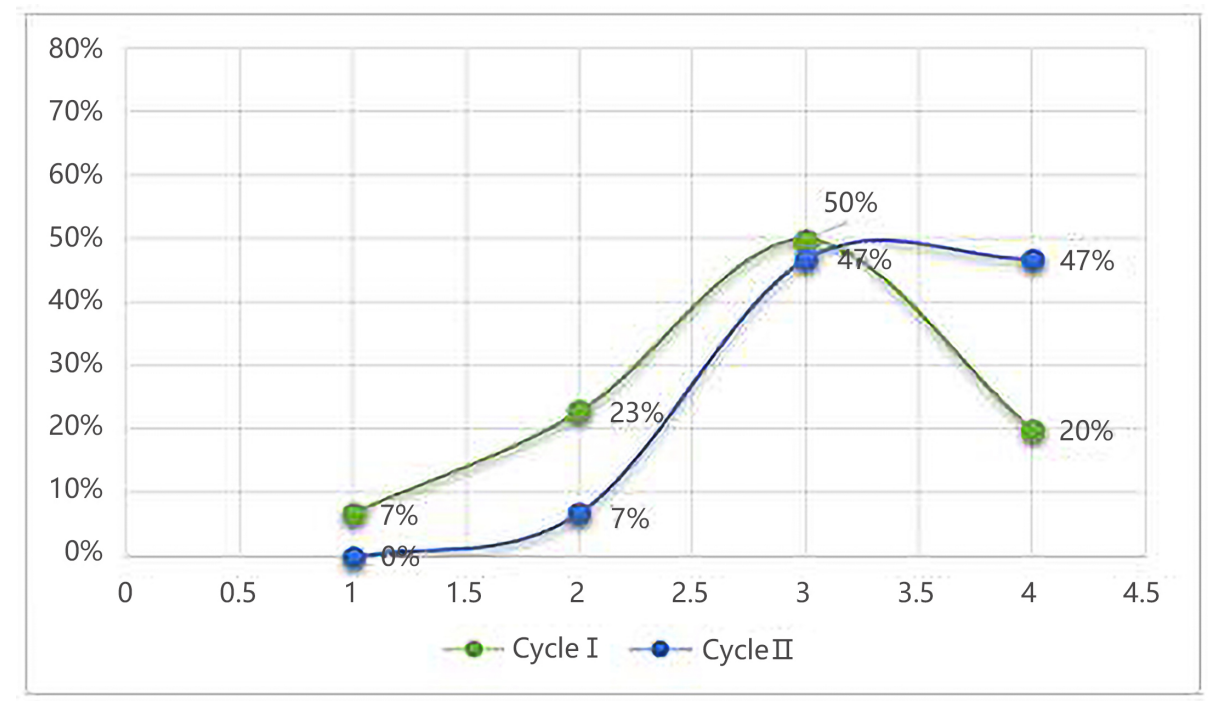

Figure 5. Hard Skill Competence Distribution 
Indicator improvement stated as competence in Figure 5. The "less competent" aspect of 7\% can be improved so that in cycle II it becomes $0 \%$. In the "competent enough" indicator it is $23 \%$ at the initial cycle and then improved to $7 \%$. In the "competent" indicator, it was initially $50 \%$, then improved to $47 \%$. As well as the "very competent" indicator initially only $20 \%$ increased to $47 \%$. Thus, the success of the second cycle has reached the set target, which is more than $80 \%$ in and above the category of "competent enough".

Overall the increase in the Cycle during the learning process with the PBL method for gasoline engine curriculum is shown in the following diagram:

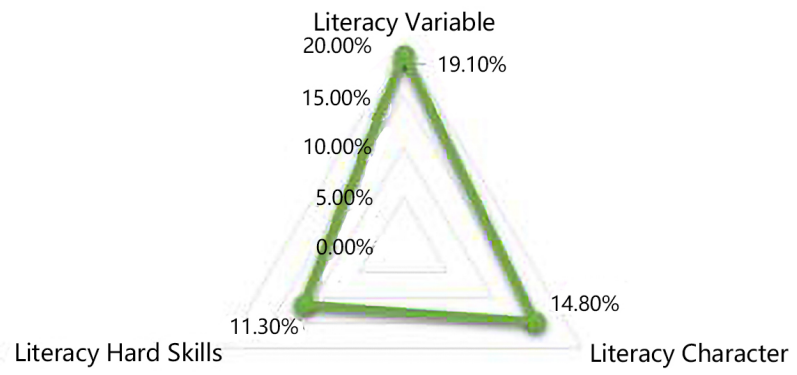

Figure 6. Learning outcome Percentage Improvement using PBL

The results obtained are success indicators in implementing PBL [13], [24]. The thing that needs to be observed is the cycle of action in learning. Good supervision and evaluation will produce good quality too [25]. PBL methods, literacy movements, and integration of character values can be applied to curricula with the same characteristics.

\section{Conclusions}

From the results and discussion, it can be concluded that (a) the literacy movement was seen as successfully implemented with an increase of $19.1 \%$; (2) educating character values improves student behavior by $14.8 \%$; and (c) strengthening competency in the gasoline engine curriculum is improved by $11.3 \%$ positively. Literacy has a positive effect on improving or strengthening students' characteristics and competencies during learning

\section{Acknowledgements}

This research is a condition of taking the Postgraduate Program at Yogyakarta State University.

\section{Noted}

The authors of this article, have the same contribution.

\section{REFERENCES}

[1] P. G.d, 'Impact of Industry 4. 0 on sustainable development', Международный Журнал Гуманитарных И Естественных Наук, no. 7, 2017.

[2] V. Mau and A. Ulyukaev, 'Global crisis and challenges for Russian economic development', Russ. J. Econ., vol. 1, no. 1, pp. 4-29, Mar. 2015.

[3] Ari, 'Revitalisasi Pendidikan Vokasi', Direktorat Pembinaan SMK. [Online]. Available: https://psmk.kemdikbud.go.id/k onten/2277/revitalisasi-pendidikan-vokasi.[Accessed:22-O ct-2019].

[4] T. Wrahatnolo and Munoto, '21 st centuries skill implication on educational system', IOP Conf. Ser. Mater. Sci. Eng., vol. 296, p. 012036, Jan. 2018.

[5] T. Erdogan, 'Research Trends in Dissertations on PBL: A Content Analysis Study', Procedia - Soc. Behav. Sci., vol. 197, pp. 308-315, Jul. 2015.

[6] M. Prince, 'Does Active Learning Work? A Review of the Research', J. Eng. Educ., vol. 93, no. 3, pp. 223-231, 2004.

[7] R. Phungsuk, C. Viriyavejakul, and T. Ratanaolarn, 'Development of a problem-based learning model via a virtual learning environment', Kasetsart J. Soc. Sci., vol. 38, no. 3, pp. 297-306, Sep. 2017.

[8] N. Hirça, 'Impact of problem-based learning to students and teachers', vol. 12, no. 1, p. 19, 2011.

[9] D. A. Sudjimat, 'Pengembangan Model Pendidikan Soft Skill Melalui Pembelajaran Pada Program Studi Pendidikan Teknik Mesin FT UM', Teknol. Dan Kejuru. J. Teknol. Kejuru. Dan Pengajarannya, vol. 33, no. 2, Aug. 2012.

[10] R. E. Islami, I. J. Sari, S. Sjaifuddin, M. Nurtanto, M. Ramli, and A. Siregar, 'An Assessment of Pre-service Biology Teachers on Student Worksheets Based on Scientific Literacy', J. Phys. Conf. Ser., vol. 1155, p. 012068, Feb. 2019.

[11] A. Zaharim, Y. M. Yusoff, M. Z. Omar, A. Mohamed, and N. Muhamad, 'Employers' perceptions and expectation toward engineering graduates: a study case', 2009.

[12] E. Ceker and F. Ozdamli, 'Features and Characteristics of Problem Based Learning', Cypriot J. Educ. Sci., vol. 11, no. 4, pp. 195-202, 2016.

[13] M. Nurtanto et al., 'Information media literacy to improve working concept comprehension of ignition system with contact breaker through problem based learning', presented at the Proceedings of International Conference of Social Science, ICOSS 2018, Denpasar, Indonesia, 2019.

[14] E. H. J. Yew and H. G. Schmidt, 'Evidence for constructive, self-regulatory, and collaborative processes in problem-based learning', Adv. Health Sci. Educ. Theory Pract., vol. 14, no. 2, pp. 251-273, May 2009.

[15] M. Nurtanto, S. Nurhaji, J. A. Baser, and Y. Yadin, 'Problem-Based Learning Implementation: Improvement in 
Learning Process and Results in Vocational Higher Education', J. Pendidik. Teknol. Dan Kejuru., vol. 24, no. 2, pp. 203-212, Sep. 2018.

[16] M. Dondlinger and J. McLeod, 'Solving Real World Problems With Alternate Reality Gaming: Student Experiences in the Global Village Playground Capstone Course Design', Interdiscip. J. Probl.-Based Learn., vol. 9, no. 2, Jan. 2015.

[17] R. McTaggart, Action Research: A Short Modern History. Deakin University, 1991.

[18] G. B. Leighbody and D. M. Kidd, Methods of Teaching Shop and Technical Subjects. Thomson Delmar Learning, 1968.

[19] M. Booth, 'Assessment of Physical Activity: An International Perspective', Res. Q. Exerc. Sport, vol. 71, no. sup2, pp. 114-120, Jun. 2000.

[20] O. Akınoğlu and R. Ö. Tandoğan, 'The Effects of Problem-Based Active Learning in Science Education on Students' Academic Achievement, Attitude and Concept Learning', Eurasia J. Math. Sci. Technol. Educ., vol. 3, no. 1, pp. 71-81, Jun. 2007.

[21] N. H. Hairuddin, 'The Use of Problem Based Learning (PBL) Method in Teaching English Writing at SMAN 5 Makassar', SELTICS, vol. 1, no. 1, pp. 1-9, Dec. 2018.

[22] J. Thomas, T. Aeby, G. Kamikawa, and B. Kaneshiro, 'Problem based learning and academic performance in residency', Hawaii Med. J., vol. 68, no. 10, pp. 246-248, Nov. 2009.

[23] M. Nurtanto and H. Sofyan, 'Implementasi problem-based learning untuk meningkatkan hasil belajar kognitif, psikomotor, dan afektif siswa di SMK', J. Pendidik. Vokasi, vol. 5, no. 3, pp. 352-364, 2015.

[24] M. Nurtanto, S. Nurhaji, D. Widjanarko, M. B. R. Wijaya, and H. Sofyan, 'Comparison of Scientific Literacy in Engine Tune-up Competencies through Guided Problem-Based Learning and Non-Integrated Problem-Based Learning in Vocational Education', J. Phys. Conf. Ser., vol. 1114, p. 012038, Nov. 2018.

[25] M. Nurtanto, D. Widjanarko, H. Sofyan, Rabiman, and M. B. Triyono, 'Learning by Creating: Transforming Automotive Electrical Textual Material into Visual Animation as A Creative Learning Products', Int. J. Sci. Technol. Res., vol. 8, no. 10, Oct. 2019. 